\title{
The knowledge of undergraduate dental students and dentists about antibiotic prophylaxis in patients at risk for infective endocarditis
}

\author{
Conhecimento de alunos de odontologia e cirurgiões-dentistas \\ em relação à profilaxia antibiótica em pacientes \\ de risco para endocardite infecciosa
}

\author{
Ana Paula Silva GANGÁ1 iD https://orcid.org/0000-0003-4784-1328 \\ Natália Bermond ARPINI ${ }^{1}$ iD https://orcid.org/0000-0002-9485-3770 \\ Tatiany Pimentel FERREIRA ${ }^{1}$ iD https://orcid.org/0000-0003-2835-2553 \\ Arlinda Lúcia Zocatelli CALENZANI² iD https://orcid.org/0000-0003-1686-050X \\ Paula Sampaio de Mello ASSIS² iD https://orcid.org/0000-0002-7972-6896
}

\begin{abstract}
Infective Endocarditis (IE) is an infection of the endocardial surface of the heart that is caused by fungi, bacteria or viruses. The high mortality and morbidity rates of IE have encouraged the adoption of preventive strategies. This study investigated the knowledge on the prevention of IE among $2^{\text {nd }}, 3^{\text {rd }}$ and $4^{\text {th }}$-year undergraduate dental students at the Escola Superior São Francisco de Assis (ESFA) and among dentists working in the municipality of Santa Teresa, ES, Brazil. Objective: The rationale for this study was to identify the gaps in their knowledge and raise awareness on the topic. Methods: The study was previously approved by the Research Ethics Committee. The sample consisted of dental students who had completed the Pharmacology for Dentistry course at the ESFA, totaling 35 2nd-year students, 29 3rd-year students, and 36 4th-year students. Thirty dentists registered in the Regional Council of Dentistry of Espírito Santo state, who were working in the municipality of Santa Teresa, ES, Brazil, were also included. All participants were given a questionnaire containing six objective and four subjective questions to assess their knowledge regarding the definition of IE, high-risk patients, dental procedures known to cause bacteremia, recommended dosage regimens for high risk patients, and additional care in the assistance of these patients. The questionnaires' responses were reviewed following the American Heart Association (AHA) guidelines for disease prevention published in 2007. Results: The analysis of the results revealed a low rate of correct responses among students and dentists. The questions with the lowest rate of correct responses were those addressing the identification of patients at high risk for heart conditions and the dental procedures known to cause bacteremia, with no significant differences between the four groups analyzed $(P>0.05)$. Third-year dental students presented a frequency of correct responses significantly lower than that of the other groups $(P<0.001)$, which did not differ from each other. To conclude, all participants demonstrated poor knowledge about the topic, particularly $3^{\text {rd }}$-year dental students. Conclusion: These results reinforce the need for informative measures to raise awareness and improve the quality of dental care provided to the population.
\end{abstract}

Indexing terms: Antibiotic prophylaxis. Dentists. Endocarditis. Students, dental.

$\boldsymbol{\nabla} \mathbf{\nabla} \boldsymbol{\nabla}$

1 Estudante de Odontologia na Escola Superior São Francisco de Assis. Rua Bernardino Monteiro,700, Dois Pinheiros, Santa Teresa, ES, Brasil. Correspondence to: PSM Assis. E-mail: <paulasampaiomello@gmail.com>.

2 Escola Superior São Francisco de Assis. Santa Teresa, ES, Brasil.

$\boldsymbol{\nabla v} \mathbf{v}$

How to cite this article

Gangá APS, Arpini NB, Ferreira TP, Calenzani ALZ, Assis PSM. Knowledge in relation to antibiotic prophylaxis in patients at risk for Infective Endocarditis. RGO, Rev Gaúch Odontol. 2020;68:e20200046. http://dx.doi.org/10.1590/1981-863720200004620180006 


\section{RESUMO}

A Endocardite Infecciosa (EI) é definida como um processo infeccioso que envolve a superfície do endocárdio e que pode ser causada por fungos, bactérias ou vírus. Devido aos altos índices de mortalidade e morbidade associados a esta doença, as ações voltadas para a sua prevenção são de grande importância. Objetivo: O objetivo do presente trabalho foi avaliar o conhecimento de acadêmicos de odontologia matriculados no segundo, terceiro e quarto anos do curso na Escola Superior São Francisco de Assis (ESFA) e de profissionais de odontologia atuantes no município de Santa Teresa-ES em relação à prevenção de Endocardite Infecciosa, com o intuito de identificar os pontos falhos e promover uma maior divulgação acerca do assunto. Métodos: Após aprovação pelo Comitê de Ética em Pesquisa, foram incluídos alunos do curso de odontologia da ESFA que já haviam cursado a disciplina de farmacologia aplicada à odontologia, totalizando 35 alunos do segundo ano, 29 do terceiro ano e 36 do quarto ano. Também foram incluídos 30 cirurgiões-dentistas devidamente inscritos no CRO-ES e que atuam no município de Santa Teresa-ES. Todos os grupos responderam a um questionário formado por seis perguntas objetivas e quatro discursivas que avaliaram o nivel de conhecimento quanto ao conceito da El, grupos de pacientes considerados de alto risco para a doença, procedimentos odontológicos causadores de bacteremia, regimes posológicos recomendados para pacientes de risco e cuidados adicionais no atendimento destes pacientes. Os questionários foram corrigidos de acordo com as diretrizes publicadas em 2007 pela American Heart Association (AHA) para prevenção da doença. Resultados: Em virtude da análise dos resultados, pôde-se observar um baixo índice de acertos tanto por parte dos alunos quanto dos profissionais. As perguntas com os menores índices de acerto estavam relacionadas à identificação dos pacientes com condições cardíacas de alto risco e dos procedimentos odontológicos causadores de bacteremia, não havendo diferenças significativas entre os quatro grupos analisados ( $p>0,05)$. Ao comparar a quantidade total de acertos, alunos cursando o terceiro ano do curso de odontologia apresentaram um número significativamente menor em comparação com os demais grupos ( $p<0,001)$, que não diferiram entre si. Conclusão: Estes resultados exigem a implementação de medidas informativas para melhoria da qualidade do serviço odontológico prestado à população.

Termos de indexação: Antibioticoprofilaxia. Odontólogos. Endocardite. Estudantes de Odontologia.

\section{INTRODUCTION}

Infective Endocarditis (IE) is a rare infectious condition of the endocardial surface of the heart. Despite current advances in its diagnosis and treatment modalities, IE continues to have high morbidity and mortality rates worldwide [1-3]. According to Chen et al. [4], IE has an annual incidence as high as 2 to 7.9 deaths per 100,000 individuals. Fungi, virus and especially bacteria can colonize the endocardium wall, internal musculature and cardiac valves, and more severe cases may prove difficult to manage and ultimately result in death [5].

IE develops in injured regions of the vascular endothelium. Patients with cardiovascular disorders may have an abnormality in blood flow that causes an endothelial lesion. The injured endothelium then favors the deposition of fibrin and platelets and the development of uninfected thrombotic endocarditis $[1,6,7]$. Oral pathogens may have access to the bloodstream during dental care and cause transient bacteremia. The occurrence of an endothelial injury combined with the presence of circulating viable microorganisms create a favorable environment for microbial adhesion to cardiac tissues. Microbial adherence is followed by further deposition of platelets and fibrin, which cumulatively creates a vegetation on the endothelial surface. The greatest risk in this process lies is the full or partial detachment of the vegetation, obliterating blood vessels and causing embolism. The latter is the leading cause of death in patients diagnosed with IE $[1,6]$.
To prevent IE, antibiotic prophylaxis prior to certain dental procedures in at-risk patients has been recommended for approximately 60 years. Several international associations have periodically published recommendations on antibiotic prophylaxis for IE. From the oldest to the most current publications, there has been a tendency to reduce the number of cases to which prophylaxis is recommended. This is because dental procedures are capable of producing bacteremia as much as do routine daily activities such as oral hygiene, mouth rising and chewing. The current scientific evidence on the topic is highly heterogeneous and limited $[1,3,7]$. Over the years, the American Heart Association (AHA) and the European Society of Cardiology (ESC) have limited the recommendation of antibiotic prophylaxis only to patients with cardiac conditions associated with an increased risk of IE complications [1,7]. In 2008, the National Institute for Health and Clinical Excellence (NICE) interrupted the recommendation for antibiotic prophylaxis for at-risk patients prior to dental procedures. In 2015, the NICE relativized this recommendation by determining that antibiotic prophylaxis should not be routinely done in this group of patients [8-10].

Thornhill et al. [11] demonstrated that after the publication of the most recent AHA guidelines there was a decrease in the number of antibiotic prophylaxis prescriptions to patients at high and medium risk for IE. On the other hand, there was also an increase in the number of IE cases in these same groups of patients, which warrants further investigation. In Brazil, the AHA guidelines 
are mostly used in the fields of dentistry and cardiology. The AHA published its most recent recommendation in 2007, highlighting significant changes in the indication of antibiotic prophylaxis prior to dental procedures [1].

Several professionals still do not know how to manage patients at risk for $\mathrm{IE}$, which can significantly affect the quality of clinical practice. Previous studies have analyzed the knowledge of dentists and / or dental students about the topic and demonstrated a limited knowledge and the existence of many questions $[5,12]$. Common mistakes include the choice for the antibiotic and its correct dosage as well as lack of knowledge on conditions that do not pose a high risk to the patient, e.g., non-invasive dental procedures that cause bacteremia [13-18]. It was also shown that a pedagogic intervention (e.g., informative talk) can effectively improve the frequency of correct responses [19].

This study investigated the knowledge on the prevention of IE among second, third and fourth-year dental students at the Escola Superior São Francisco de Assis (ESFA) and among dentists working in the municipality of Santa Teresa, ES, Brazil.

\section{METHODS}

The knowledge and clinical conduct of study participants regarding the prevention of IE were determined by a questionnaire containing four subjective and six objective questions. The questions addressed the knowledge about case definitions of IE; heart conditions with a high risk for IE complications; dental procedures known to cause bacteremia which require antibiotic prophylaxis; antibiotic regimen indicated for both patients non-allergic and allergic to penicillin; minimum interval in between dental appointments of high-risk patients; prescription of chlorhexidine mouthwash in the postoperative period; and the frequency of communication between the dentist and the patient's cardiologist. The questionnaire also included questions to collect demographic information such as age, sex, and specialty and time since graduation (for dentists only).

The questionnaire was applied to undergraduate dental students (second, third and fourth year) and to dentists. The inclusion criteria for dentists were to be registered in the Regional Council of Dentistry of Espírito Santo state and to work in the municipality of Santa Teresa, ES, Brazil. The inclusion criteria for dental students were to be enrolled in the dental course at the Escola Superior São Francisco de Assis (ESFA) and to have successfully completed the Pharmacology for Dentistry course.

Participants were allocated into four groups for pairwise comparison of results. The sample size consisted of 35 second-year students, 29 third-year students and 36 fourth-year students, selected between December 2017 and February 2018 by means of a stratified random sampling from a total population of 77 second-year students, 59 third-year students and 81 fourth-year students. Of a population of 50 dentists registered in the regional council and working in the municipality of Santa Teresa, 30 were selected by simple random sampling. The students were approached collectively in the classroom and invited to participate in the study, while dentists were approached individually in their workplaces.

The questionnaire was responded during the contact with the researchers and was not allowed to be taken anywhere else. Search for information from external sources was not allowed. Chart 1 shows the criteria used to review the responses. The standardization of the review

Chart 1. Criteria for review of the questionnaire applied to undergraduate dental students and dentists.

\begin{tabular}{|c|c|}
\hline Variable & Review criteria \\
\hline Definition of IE & Should include keywords such as "infection", "endocardium", "bacteria", among others. \\
\hline Heart conditions & $\begin{array}{l}\text { The correct response corresponded to the assignment of four correct alternatives and no incorrect } \\
\text { alternative. }\end{array}$ \\
\hline Dental procedures & $\begin{array}{l}\text { The correct response corresponded to the assignment of seven correct alternatives and no incorrect } \\
\text { alternative. }\end{array}$ \\
\hline Standard regimen & $2 \mathrm{~g}$ amoxicillin by mouth, 30 to 60 minutes before intervention \\
\hline Regimen for allergic patients & $\begin{array}{l}\text { 2g Cefalexin or } 600 \mathrm{mg} \text { Clindamycin or } 500 \text { mg Azithromycin or } 500 \text { mg Clarithromycin, } 30 \text { to } 60 \text { minutes } \\
\text { before intervention }\end{array}$ \\
\hline Minimal interval between dental appointments & Minimum of 10 days in between appointments \\
\hline Prescription of mouthwashes & Three days maximum \\
\hline
\end{tabular}


criteria was based on the most recent AHA guidelines published in 2007 [1].

The data were tabulated and analyzed statistically. The proportions test (Z-Test) was used to compare the percentage of correct responses between groups. The total number of correct responses was compared between groups by Kruskal-Wallis followed by Dunn's post-hoc test. The data were analyzed in Bioestat ${ }^{\circledR}$ version 5.0, with a $5 \%$ significance level $(\alpha=0.05)$.

This study was previously approved via Plataforma Brasil by the Research Ethics Committee of the Cassiano Antônio de Moraes University Hospital at the Federal University of Espírito Santo, under protocol CAAE 77755717.7.0000.5071. In accordance with the Resolution n. 466/2012 of the Ministry of Health's National Health Council, undergraduate dental students and dentists signed an informed consent form to authorize their voluntary participation in the study.

\section{RESULTS}

A hundred dental students selected by stratified random sampling were included in the study. Of these, 35 were second-year students, 29 were third-year students and 36 were fourth-year students. The mean average of participating students was 21.9 years $( \pm 3.4)$ and $78 \%$ of them were females. Thirty dentists were selected by simple random sampling, with an average $7.9( \pm 7.0)$ years since graduation and the following specialty degrees: general practice $(30 \%)$, orthodontics (13\%), endodontics (10\%) and implantology (13\%). The demographic information on age and sex distribution of students and dentists is shown in table 1.

Table 2 summarizes the participants' responses regarding the definition of IE, high-risk cardiac conditions, bacteremia-causing dental procedures which require antibiotic prophylaxis, antibiotic regimen for allergic and non-allergic patients, minimum interval in between dental appointments for at-risk patients, and length of postoperative use of $0.12 \%$ chlorhexidine mouthwash.

While $87 \%$ of the students reported knowing the definition of $\mathrm{IE}$, only $47 \%$ of them described it correctly. Similarly, $97 \%$ of the dentists responded that they knew the definition of IE, but only $63 \%$ of them described it adequately, with no statistical difference between students and dentists ( $P>0.05$ ). Even though $88 \%$ of the students and $90 \%$ of the dentists would correctly prescribe an antibiotic drug for patients not allergic to penicillin, only $27 \%$ of the students and $53 \%$ of the dentists correctly reported the dose and dosage regimen. Third-year dental students responded correctly to this question, yet at a significantly lower frequency than dentists $(P<0.05)$, with no significant differences between the other groups. Similarly, $85 \%$ of the students and $87 \%$ of the dentists chose the appropriate antibiotic for patients allergic to penicillin, but only $31 \%$ and $30 \%$ of them, respectively, indicated the correct dose and dosage regimen. Thirdyear dental students presented a significantly lower rate of correct responses than second-year students $(P<0.05)$, with no significant differences compared to the other groups.

Among the twelve cardiac conditions listed in the questionnaire, only four are of high risk for IE. Although $64 \%$ of the students and $70 \%$ of the dentists identified these four conditions correctly, only $5 \%$ and $7 \%$ of them, respectively, did not assign incorrect conditions. Of the ten dental procedures listed in the questionnaire, only seven should be preceded by antibiotic prophylaxis. In this study, $18 \%$ of the students and $43 \%$ of the dentists identified the seven procedures correctly, but only $6 \%$ and $17 \%$ of them, respectively, did not report incorrect procedures, with no significant difference between the groups $(P>0.05)$.

The minimum interval in between dental appointments for patients at risk for IE should be 10 days to effectively avoid the selection of resistant microorganisms.

Table 1. Demographics of undergraduate dental students and dentists participating in this study

\begin{tabular}{lcccc}
\hline \multirow{2}{*}{ Variable } & \multicolumn{3}{c}{ Undergraduate dental students } & \multicolumn{1}{c}{ Dentists } \\
\cline { 2 - 4 } & $2^{\text {nd }}$ year & $3^{\text {rd }}$ year & $22.4 \pm 1.8$ & $32.8 \pm 8.9$ \\
\hline Age (mean \pm standard deviation) & $21.1 \pm 4$ & $22.3 \pm 4.2$ & $7(19.44 \%)$ & $15(50 \%)$ \\
Males & $6(17.14 \%)$ & $9(31.03 \%)$ & $29(80.56 \%)$ & $15(50 \%)$ \\
\hline TOTAL & $29(82.86 \%)$ & $20(68.97 \%)$ & $\mathbf{3 6}$ & $\mathbf{3 0}$ \\
\hline
\end{tabular}


Table 2. Responses of undergraduate dental students and dentists to questions addressing the prevention of IE.

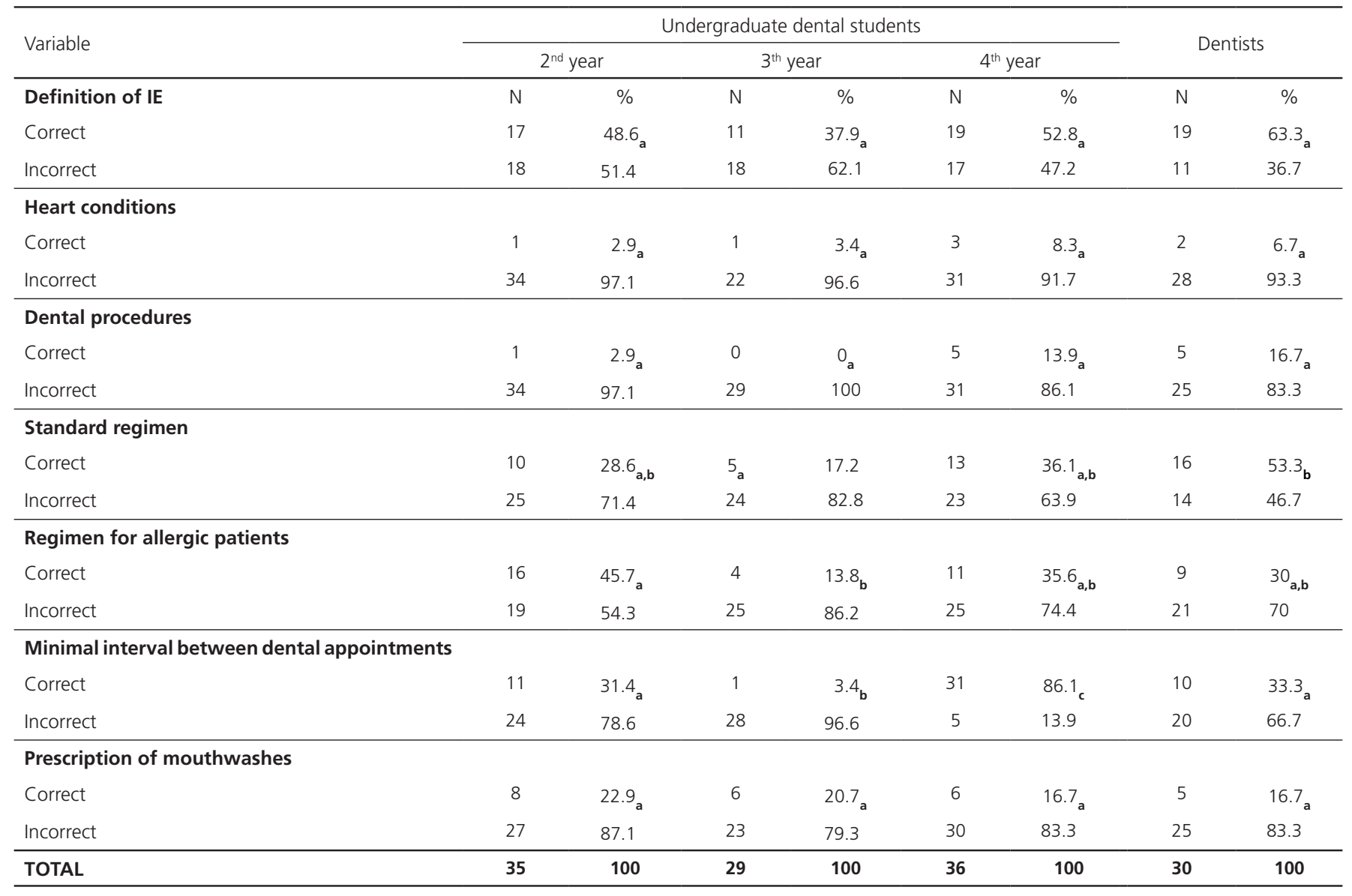

* Different letters indicate statistically significant differences.

Based on this, $43 \%$ of the students and $33.3 \%$ of the dentists answered correctly the questionnaire. Fourth-year dental students performed better than those of other groups, while third-year students performed significantly worse than the others $(P<0.05)$.

Post-operative $0.12 \%$ chlorhexidine mouthwash should be prescribed for patients at risk for IE for a maximum period of three days, in order to avoid the selection of resistant microorganisms. In this regard, $20 \%$ of the students and $16.7 \%$ of the dentists responded the question correctly, with no statistically significant differences among the four groups analyzed $(P>0.05)$.

Similar unsatisfactory results were found among students and dentists with regard to the following aspects: high-risk cardiac conditions, dental procedures that should be preceded by antibiotic prophylaxis in at-risk patients, and prescription of postoperative chlorhexidine mouthwash.
A higher frequency of correct responses was found for IE definitions, although there were no significant differences among the four groups.

Dentists were further asked about the frequency and means of contact with the cardiologist responsible for the patient at risk of developing IE. Most dentists reported contacting the cardiologist by letter, telephone and / or email, with $16.7 \%$ of them not making any contact.

Figure 1 shows the median number of correct responses in each group, the distribution in the first and third quartiles, and the minimum and maximum values of correct responses. Second- and fourth-year dental students presented similar correct response rates between each other and as compared to dentists, with no statistically significant differences between the three groups. In contrast, third-year dental students presented a lower rate of correct responses in relation to those of the other groups $(P<0.05)$. 


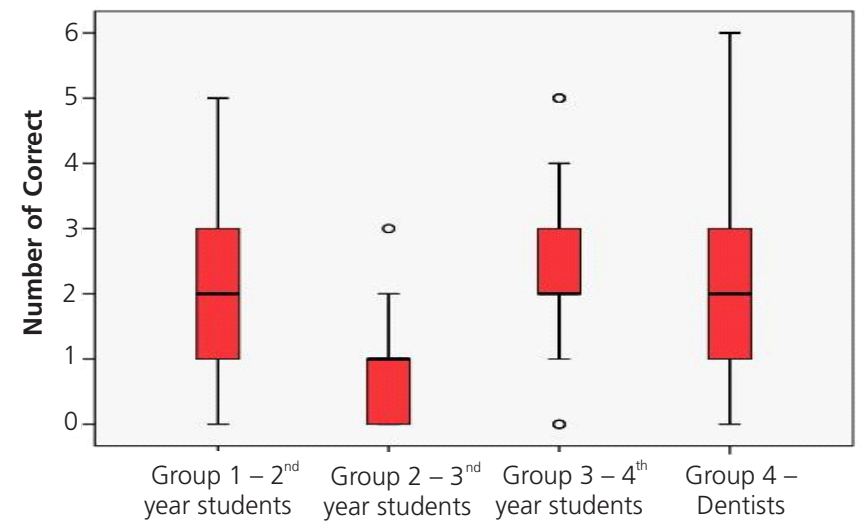

Figure 1. Distribution of the number of correct responses in the study groups.

\section{DISCUSSION}

IE has high mortality rates worldwide, which means that students and dentists should be able to manage patients with IE and / or those at high risk of developing the condition and associated complications. This study applied questionnaires to undergraduate students and dentists to identify their knowledge on antibiotic prophylaxis and management of patients at risk of developing IE.

The results of the present study revealed that $63.4 \%$ of the dentists and $47 \%$ of the students responded correctly the questions addressing the definition of IE. These findings are in agreement with those of Rocha et al. [12], whom reported that $78 \%$ and $44 \%$ of dentists and students, respectively, responded correctly on the definition of IE.

According to the 2007 AHA guidelines, only cardiac conditions classified as high risk should be eligible for antibiotic prophylaxis, excluding moderate and low risk conditions. In this study, the four correct response alternatives on the topic were properly selected by both students and dentists, with heart valve prosthesis the most frequent condition. These findings are in line with other studies in the literature with dental students and dentists $[5,12,16,19]$. Among the high-risk cardiac conditions, congenital heart disease was the least frequently reported - $79 \%$ and $30 \%$ by students and dentists, respectively, as confirmed by Cloitre et al. [16]. In this question, participants mistakenly considered low and / or moderate risk conditions as being eligible for antibiotic prophylaxis.

The most frequently reported invasive, bacteremiacausing dental procedureswere exodontia and dental implant, which is in line with previous studies $[12,14,17,18,20]$. The seven correct response alternatives in this question were frequently selected, similarly to what was previously described for heart conditions. The overall frequency of correct response for this question was $8.5 \%$, regardless of the group (students or dentists), which is significantly lower than what was observed by Cloitre et al. [16] 30.4\% among dentists.

Less than half of the participating students (28\%) knew the correct dosage of the prophylactic antibiotic regimen in patients not allergic to penicillin ( $2 \mathrm{~g}$ amoxicillin by mouth, 30 minutes to 1 hour before intervention), which is consistent with the findings of Albuquerque et al. [13] (13.6\%). Overall, 53.3\% of the participating dentists reportedly knew the dosage regimen for this group of patients, similarly to what was observed in the studies by Rocha et al. [12] (53\%) and Ghaderi et al. [17] (57\%). Vasconcelos \& Vieira [5] observed a greater frequency of correct responses $(81.8 \%)$ among dentists in questions related to the prophylactic antibiotic regimen, while a lower frequency of correct responses was found by Cloitre et al. [16] (22.5\%) and Nomura et al.[18] (19.5\%).

The study by Nascimento et al. [19] compared the responses of dentists before and after an educational talk. Following the talk, the authors observed an increase from $6.1 \%$ to $87.9 \%$ in the correct prescription of a prophylactic antibiotic regimen for at-risk patients allergic to penicillin. In our study, fourth-year dental students showed a better performance than those in the other groups. This may be explained by the fact that the program content of the Pharmacology for Dentistry course is revisited two years later in other courses, Integrated Clinics for Special Patients and Geriatric Dentistry I. The opportunity of fourth-year dental students to revisit the topic may be comparable to the educational talk of Nascimento et al.'s study [19] and explain the greater number of correct responses in this group.

Although the study participants were able to identify patients at risk for IE and the major dental procedures requiring antibiotic prophylaxis, there were few correct responses regarding antimicrobial prescription and dosage regimen. Consistent with this, Ryalat et al. [12] and Albuquerque et al. [13] reported a relatively high percentage of dentists and undergraduate students, respectively, whom were unaware of international guidelines on antibiotic prophylaxis. A high number of incorrect responses was mainly attributed to the choice 
for incorrect response alternatives, which indicates a heterogenous knowledge on the topic.

There was a relatively low number of correct responses about the minimum interval between dental appointments - 43\% for students and 33.4\% for dentists. The most commonly reported minimum intervals between dental appointments were seven and fifteen days. Vasconcelos \& Vieira [5] reported an even lower correct response rate $(18 \%)$, in which the majority of interviewed dentists indicated a minimum interval of seven days in between the dental visits.

Rocha et al. [12] reported that $67 \%$ of dentists are in constant contact with the patient's cardiologist while $24 \%$ of them have an occasional contact. In our study, $66.6 \%$ of the surveyed dentists reported to be in constant contact as compared to $16.7 \%$ having an occasional contact. These findings are in agreement with the study by Vasconcelos \& Vieira [5], who demonstrated that 54.2\% and $45.8 \%$ of the dentists had a constant and occasional contact with the patient's cardiologist, respectively.

There was greater agreement between students and dentists in properly selecting cardiac conditions of high risk for IE than high risk dental procedures. Most students and dentists correctly selected the cardiac conditions of high risk for $\mathrm{IE}$, which were the presence of valvular prosthesis, history of endocarditis, congenital heart disease and valvopathy after cardiac transplantation. The most frequently reported dental procedures that require prior antibiotic prophylaxis according to dental students and dentists were exodontia and dental implant. Nevertheless, endodontic treatment, anesthesia of infected tissues and subgingival scaling and root planing, which are correct response alternatives, were more frequently selected by dentists. The questions related to the clinical management of high-risk patients had a greater frequency of incorrect responses. Study participants were not able to indicate which prophylactic regimens are indicated for patients at high risk for IE or what specific care procedures should be taken.

Collectively, our results demonstrate an unsatisfactory knowledge of undergraduate dental students and dentists on antibiotic prophylaxis for IE. Two main findings warrant further attention, namely: lack of antibiotic prescription when needed, which could expose the patient to a higher risk of developing $\mathrm{IE}$; and the indiscriminate use of antimicrobials when not needed, which could contribute to the selection of resistant strains. Given the above, the responsible and evidence-based practice of dentistry should be grounded on high-level knowledge and constant training.

\section{CONCLUSION}

It is concluded that the knowledge of the surveyed dentists has not been lost throughout the years as it was found to be similar to that of undergraduate dental students. Nevertheless, the results observed were unsatisfactory, given that study participants, in particular third-year dental students, showed lack of knowledge on relevant topics. Informative measures should be adopted to improve the training of students and dentists on the prevention of $\mathrm{IE}$, as the lack of knowledge may result in negligent conduct in the care of high-risk patients.

\section{Collaborators}

APS GANGÁ, NB ARPINI and TP FERREIRA, data collection, tabulation and manuscript writing. ALZ CALENZANI, manuscript revision and corrections. PS MELLO, study design, supervision, and manuscript revision.

\section{REFERENCES}

1. Wilson W, Taubert K, Gewitz M, Lockhart PB, Baddour LM, Levison $M$, et al. Prevention of infective endocarditis: guidelines from the American Heart Association: Circulation. 2007;116(15):1736-54. http://dx.doi.org/10.1161/ CIRCULATIONAHA.106.183095

2. Andrade ED. Terapêutica medicamentosa em Odontologia. $3^{\text {a }}$ ed. São Paulo: Artes Médicas; 2014.

3. Cahill TJ, Harrison JL, Jewell P, Onakpoya I, Chambers JB, Dayer $M$, et al. Antibiotic prophylaxis for infective endocarditis: a systematic review and meta-analysis. Heart. 2017;103(12):937-44. http://dx.doi.org/doi:10.1136/heartjnl-2015-309102

4. Chen P, Tung Y, Wu PW, Wu L, Lin Y, Chang C, et al. Dental procedures and the risk of infective endocarditis. Medicine. 2015;94(43):1-6. http://dx.doi.org/10.1097/MD.00000000 00001826

5. Vasconcellos LM, Vieira FLD. Conhecimento dos cirurgiõesdentistas do município de Vassouras-RJ sobre a endocardite infecciosa. Rev Pró-inverSUS. 2011;2(2):17-28.

6. Werdan K, Dietz S, Löffler B, Niemann S, Bushnaq H, Silber R, et al. Mechanisms of infective endocarditis: pathogen - host interaction and risk states. Nat Publ Gr. 2013;11(1):35-50. http://dx.doi.org/10.1038/nrcardio.2013.174 
7. Habib G, Hoen B, Tornos P, Thuny F, Prendergast B, Vilacosta I, et al. Guidelines on the prevention, diagnosis, and treatment of infective endocarditis (new version 2009): the Task Force on the Prevention, Diagnosis, and Treatment of Infective Endocarditis of the European Society of Cardiology (ESC). Eur Heart J. 2009;30(19):2369-413. http://dx.doi.org/10.1093/ eurheartj/ehp285

8. NICE. Prophylaxis against infective endocarditis: antimicrobial prophylaxis against infective endocarditis in adults and children undergoing interventional procedures. London: NICE; 2008.

9. NICE. Prophylaxis against infective endocarditis: antimicrobial prophylaxis against infective endocarditis in adults and children undergoing interventional procedures. London: NICE; 2016.

10. Thornhill MH, Dayer M, Lockhart PB, McGurk M, Shanson $D$, Prendergast $B$, et al. A change in the NICE guidelines on antibiotic prophylaxis. BDJ. 2016;221(3):112-4. http://dx.doi. org/10.1038/sj.bdj.2016.554

11. Thornhill MH, Gibson TB, Cutler E, Dayer MJ, Chu VH, Lockhart $\mathrm{PB}$, et al. Antibiotic prophylaxis and incidence of endocarditis before and after the 2007 AHA recommendations. J Am Coll Cardiol. 2018;72(20):2443-54. http://dx.doi.org/doi: 10.10 16/j.jacc.2018.08.2178

12. Rocha LMA da, Oliveira PRD, Santos PB, Jesus LA De, Stefani CM. Conhecimentos e condutas para prevenção da endocardite infecciosa entre cirurgiões-dentistas e acadêmicos de Odontologia. Robrac. 2008;17(44):146-53.

13. Albuquerque CC, Sousa JCN, Veloso HHP, Paiva MDEB, Silva PV, Queiroga AS. Conhecimento sobre endocardite infecciosa entre estudantes de Odontologia. Comun Ciências Saúde. 2013;24(4):331-40.

14. Ryalat S, Hassona Y, Al-Shayyab M, Abo-Ghosh M, Sawair F. Dentists' knowledge and practice regarding prevention of infective endocarditis. Eur J Dent. 2016;10(4):480-5. http:// dx.doi.org/doi: 10.4103/1305-7456.195158

15. Jain P, Stevenson T, Sheppard A, Rankin K, Compton SM, Preshing W. et al. Antibiotic prophylaxis for infective endocarditis. J Am Dent Assoc. 2015;146(10):743-50. http:// dx.doi.org/10.1016/j.adaj.2015.03.021

16. Cloitre A, Durval X, Hoen B, François A, Lesclous P. A nationwide survey of French dentists' knowledge and implementation of current guidelines for antibiotic prophylaxis of infective endocarditis in patients with predisposing cardiac conditions. Oral Surg Oral Med Oral Pathol Oral Radiol. 2018;125(4):295303. http://dx.doi.org/doi: 10.1016/j.0000.2017.10.002

17. Ghaderi F, Oshagh M, Dehghani R, Hasanshahi R. Awareness of Iranian's General Dentists regarding the latest prophylaxis guideline for prevention of infective endocarditis. J Dent Shiraz Univ Med Scien. 2013;14(1):6-12.

18. Nomura R, Kokomoto K, Takahiro O, Nakatani S, Ooshima T, Nakano K. Current knowledge among Japanese experienced general dentists regarding prevention of infective endocarditis. Odontology. 2018;106(3):297-305. http://dx.doi.org/doi: 10.10 07 / s10266-018-0344-7

19. Nascimento EM, Santos MF, Pinto TC de A, Cavalcanti SDLB, Fontes $\mathrm{L}$ de BC, Granville-Garcia AF. Abordagem odontológica de pacientes com risco de endocardite: um estudo de intervenção. Odonto. 2011;19(37):107-16.

20. Al-Fouzan AF, Al-Shinaiber RM, Al-Baijan RS, Al-Balawi MM. Antibiotic prophylaxis against infective endocarditis in adult and child patients knowledge among dentists in Saudi Arabia. Saudi Med J. 2015;36(5):554-61. http://dx.doi.org/ doi: 10.15537 / smj.2015.5.10738

Received on: 29/10/2018 Final version resubmitted on: 23/3/2019 Approved on: 22/5/2019 